\title{
Mengembangkan Perangkat Pembelajaran Kalkulus Integral Berbasis Model Pengajuan dan Pemecahan Masalah untuk Meningkatkan Kemampuan Berpikir Kreatif Mahasiswa
}

\author{
Edy Waluyo ${ }^{1 *}$, Sri Supiyati ${ }^{2}$, Muhammad Halqi $^{3}$ \\ ${ }^{1,2,3}$ Program Studi Pendidikan Matematika, Universitas Hamzanwadi \\ *edywaluyo2002@yahoo.co.id
}

\begin{abstract}
Abstrak
Studi ini bertujuan untuk mengembangkan perangkat pembelajaran pada matakuliah Kalkulus Integral berupa desain instruksional atau pembelajaran pada konsep volume benda putar matakuliah Kalkulus Integral yang mempunyai efek potensial dalam peningkatan kemampuan berpikir kreatif mahasiswa berbasis model pengajuan dan pemecahan masalah. Penelitian menggunakan penelitian pengembangan model Borg and Gall dengan tahapan pengembangan desain pembelajaran mulai dari analisis kebutuhan, desain produk, pengembangan produk, implementasi dan evaluasi produk. Subyek penelitian sebanyak 34 mahasiswa Program Studi Pendidikan Matematika Universitas Hamzanwadi yang memprogramkan matakuliah Kalkulus Integral yang terdiri dari 6 orang laki laki dan 28 orang wanita. Pengumpulan data menggunakan instrumen pedoman atau lembar validasi produk, angket kepraktisan produk dan posttest untuk mengukur kepraktisan dan efek potensial produk. Data dianalisis dengan analisis deskriptif. Dari hasil analisis data, desain instruksional yang disusun dan dirancang berbasis model pengajuan dan pemecahan masalah tergolong produk yang memenuhi kriteria validitas, kepraktisan dan keefektifan produk serta layak untuk diimplementasikan. Produk yang dikembangkan juga potensial dalam meningkatkan kemampuan berpikir kreatif mahasiswa dengan $\mathrm{N}$ Gain sebesar 0,73.
\end{abstract}

Kata kunci: berpikir kreatif, desain pembelajaran, pengajuan dan pemecahan masalah

\begin{abstract}
This study aims to develop learning set in the Integral calculus in the form of instructional design or study the concept of the volume of an Integral calculus rotating object that has a potential effect in improving student creative thinking skills based on model submission and problem-solving. The study used the Borg and Gall model development research with the stages of the development of learning design ranging from analysis, design, development, implementation, and evaluation. This study used the subject of 34 students of the University of Mathematics Education Study Program Hamzanwadi, which programmed the Integral calculus course consisting of 6 males and 28 females. Data collection using product guidelines or product validation sheets, product practices, and posttests to measure practicality and potential effects product. From the results of the data analysis, instructional design is drafted and designed based on the filing and problem-solving model of products that meet the criteria of validity, practicality, and effectiveness of products and feasible to implement. The product developed is also a potential in enhancing the students' creative thinking skills with a $\mathrm{N}-$ Gain of 0.73 .
\end{abstract}

Keywords: creative thinking, learn and solve problem, learning design 


\section{Pendahuluan}

Kemampuan berpikir kreatif seseorang dalam belajar akan menentukan hasil belajarnya. NCTM (2000) memberikan standar yakni dalam rangka mempersiapkan abad ke-21, perlu dilakukan pembelajaran sehingga setiap peserta didik memiliki kemampuan antara lain kemampuan memecahkan masalah, kemampuan berkomunikasi, dan kemampuan berpikir matematis yang didalamnya termasuk kemampuan berpikir kreatif untuk dapat menghadapi tantangan global. Menurut Yanti (2019), hasil studi PISA tahun 2015 dan TIMMS menjadi salah satu bukti bahwa pendidikan formal Indonesia lebih menekankan pada aspek berpikir tingkat rendah (low order thinking) dan jarang membiasakan siswa untuk menggunakan berpikir tingkat tinggi dalam menghadapi dan menyelesaikan masalah nyaya dalam kehidupan sehari hari. Mahmudi (2009) menyatakan bahwa kemampuan berpikir peserta didik dalam pembelajaran masih rendah, hal ini diakibatkan oleh proses kegiatan pembelajaran yang dilakukan guru belum dapat memfasilitasi peserta didik untuk menggali ide ide baru karena masih bersifat aspek mekanistis, yang hanya menghafal fakta fakta dalam matematika bukan penekanannya pada pengembangan pola piker peserta didik. Sementara itu hasil kajian PISA pada tahun 2015 di Indonesian menyebutkan bahwa kemampuan matematis yang dimiliki peserta didik dapat dikatakan masih tergolong rendah (OECD, 2016)

Lambertus (2013) menyatakan bahwa melatih serta mengembangkan kemampuan berpikir peserta didik yang salah satunya adalah berpikir kreatif merupakan tujuan penting dan utama dalam pendidikan. Berpikir kreatif sangat diperlukan seseorang ketika mereka memasuki dunia kerja. Oleh karena itu, dalam pembelajaran matematika khususnya, seorang guru dituntut untuk malakukan pembelajaran yang tidak hanya menghafal fakta fakta tetapi juga ditintut untuk melatih dan mengembangkan kemampuan berpikir kreatif peserta didik yang nantinya diperlukan untuk menghadapi dan memecahkan permasalahan dalam kehidupannya. Beberapa penelitian terkait berpikir kreatif di bidang pembelajaran matematika menyebutkan bahwa kemampuan sesorang yang diperlukan dan digunakan untuk memahami suatu masalah melalui wawasan baru atau pendekatan baru untuk memecahkan persoalan matematika merupakan kemampuan berpikir kreatif (Nadjafikhah, 2013; Gregoire, 2016; Bengi, 2015). Sementara itu, Coughlan (2007) berpendapat bahwa kemampuan berpikir kreatif merupakan inovasi seseorang yang dapat digunakan untuk mengatasi masalah.

Mahmudi (2008) mengemukakan bahwa dalam pembelajaran matematika, pengembangan kemampuan berpikir kreatif masih kurang mendapat perhatian. Penelitian yang 
dilakukan oleh Romadiastri (2013), menunjukkan bahwa sebagian besar mahasiswa kesulitan dan belum mampu menyelesesaikan soal tentang volume benda putar dengan menggunakan integral. Beberapa hasil penelitian menunjukkan bahwa untuk mengatasi persoalan tersebut dapat dilakukan proses pembelajaran demikian sehinggga terjadi proses strukturisasi aktivitas pembelajaran yang melibatkan mahasiswa dalam menyelesaikan permasalahan yang diberikan yang pada akhirnya mahasiswa dapat memilih cara yang tepat dalam memecahkan persoalan matematika yang dihadapinya (Khaulah, 2018; Siswono, 2018). Dari hasil kajian tersebut di atas, menunjukkan bahwa berpikir kreatif sangat diperlukan seseorang dalam menyelesaikan permasalahan yang dihadapi. Dalam berpikir kreatif seseorang dituntut untuk menggali ide, wawasan dan gagasan baru untuk menyelesaikan permasalahan yang dihadapi, sehingga dalam proses pembelajaran dikelas, guru atau dosen dituntut untuk dapat merancang pembelajaran yang mampu melatih danmengembangkan kemampuan berpikir peserta didik.

Sebagai alternatif solusi untuk membantu mengatasi persoalan tersebut di atas, peneliti mencoba melakukan kajian atau penelitian yang bertujuan mengembangkan produk pembelajaran yang dapat dipergunakan dalam proses pembelajaran di kelas menggunakan model atau strategi tertentu sebagai sarana bagi setiap mahasiswa dimana kemampuan berpikir kreatifnya dapat dilatih dan dikembangkan. Peneliti mencoba mengembangkan perangkat pembelajaran berupa dain pembelajaran dalam matakuliah kalkulus integral yaitu desain pembelajaran menggunakan model Pengajuan dan Pemecahan Masalah. Pembelajaran dengan model pengajuan dan pemecahan masalah merupakan model pembelajaran yang dilakukan secara sistematis, yang menggunakan ide dan gagasan baru dalam prose berpikirnya untuk menyelesaikan persoalan atau permasalahan yang diberikan. (Siswono, 2018; Ridong, 2017). Selanjutnya, suatu pembelajaran yang menggunakan prinsip dan karakteristik dengan model ini, memungkinkan mahasiswa dapat melatih dan mengembangkan kemampuan berpikir kreatif untuk menemukan kembali konsep matematika dalam memecahkan masalah matematika (Ridwan, 2018; Novianti \& Khoirotunnisa, 2016; Indriyani, 2017). Tahapan model pembelajaran pengajuan dan pemecahan matematika diawali dengan penyajian kepada mahasiswa sebuah masalah nyata untuk memudahkan mahasiswa memperoleh konsep-konsep dari hasil penyelidikan dan inkuiri sehingga pembelajaran matematika menjadi lebih bermakna (Cindy, Silver, Chinn, 2013). Hal ini mengindikasikan bahwa pembelajaran dengan model pengajuan dan pemecahan masalah dapat membantu mahasiswa dalam melatih serta mengembangkan kemampuan berpikirnya dengan mengkonstruksi pengetahuannya melalui permasalahan-permasalahan nyata yang diberikan selama pembelajaran. 
Mengacu pada paparan di atas, peneliti tertarik untuk mengembangkan produk pembelajaran berbasis model pengajuan dan pemecahan masalah matematika berupa desain pembelajaran pada matakuliah kalkulus integral dan mengimplementasikannya pada konsep volume benda putar. Pengembangan perangkat pembelajaran ini dimaksudkan untuk mendeskripsikan proses pembelajaran konsep volume benda putar dengan tahapan pembelajaran menggunakan model pengajuan dan pemecahan masalah pada matakuliah kalkulus integral.

\section{Metode}

Mengacu pada permasalahan yang akan dikaji, metode penelitian yang digunakan adalah penelitian pengembangan Borg and Gall (2007) yakni suatu proses sistematis yang dilakukan dalam mengembangkan suatu produk pendidikan dan mengacu pada pengembangan desain pembelajaran meliputi analisis kebutuhan, desain produk, pengembangan produk, implementasi dan evaluasi produk (Dick, Walter, Carey, \& Lou, 2001). Penelitian dikenakan pada 34 mahasiswa program studi pendidikan matematika Universitas Hamzanwadi pada tahun akademik 2019/2020 yang menempuh matakuliah Kalkulus Integral, dengan karakteristik 6 orang laki laki dan 28 orang perempuan.

Instrumen pengumpul data terdiri dari pedoman atau lembar validasi, angket kepraktisan dan tes hasil belajar. Pedoman validasi yang disusun terdiri dari 12 pertanyaan dengan indikator pengukuran meliputi: (a) Aspek perumusan tujuan pembelajaran, (b) Aspek isi, (c) Aspek bahasa, dan (d) Aspek waktu. Sedangkan angket kepraktisan produk terdiri dari 10 pertanyaan dengan indikator meliputi: (a) Aspek perasaan senang terhadap komponen pembelajaran, (b) Aspek perasaan kebaruan dalam pembelajaran, (c) Aspek minat dalam pembelajaran. Sedangkan tes hasil belajar tentang kemampuan berpikir kreatif mahasiswa berupa tes essay dengan indikator: (a) mampu mencetuskan gagasan (b) mampu menyajikan konsep dan gagasan baru, (c) mampu memberikan beberapa jawaban dalam memecahkan masalah, (d) mampu menyajikan sebuah konsep dengan berbagai cara yang berbeda (Gregoire, 2016). Validasi produk dilakukan oleh 2 validator di bidang pendidikan yaitu 1 ahli materi pembelajaran dan 1 ahli/praktisi pelaksana pembelajaran dan dilakukan ujicoba untuk mendapatkan instrumen yang valid. 
Kualitas produk yang dikembangkan pada penelitian ini dikatakan layak digunakan jika memenuhi kriteria kevalidan pada kategori minimal valid dengan kriteria ditunjukkan seperti tabel 1 di bawah ini.

Tabel 1. Kategori Kevalidan Desain Pembelajaran yang Dikembangkan

\begin{tabular}{cc}
\hline Interval Skor & Kriteria \\
\hline $276<X$ & Sangat Valid dan sangat Layak \\
\hline $230<\bar{X} \leq 276$ & Valid dan Layak \\
\hline $184<\bar{X} \leq 230$ & Cukup Valid dan Cukup Layak \\
\hline $138<\bar{X} \leq 184$ & Kurang Valid dan Kurang Layak \\
\hline $\bar{X} \leq 138$ & Tidak Valid dan tidak layak \\
\hline
\end{tabular}

Sementara itu, produk yang dikembangkan dikatakan praktis digunakan jika memenuhi kriteria minimal praktis berdasarkan kriteria kepraktisan yang ditetapkan seperti tabel 2 berikut.

Tabel 2. Kriteria Kepraktisan Desain Pembelajaran yang Dikembangkan

\begin{tabular}{cc}
\hline Interval Skor & Kriteria \\
\hline $72,5<X$ & Sangat Praktis \\
\hline $60,5<\bar{X} \leq 72,5$ & Praktis \\
\hline $48,5<\bar{X} \leq 60,5$ & Cukup Paktis \\
\hline $36,5<\bar{X} \leq 48,5$ & Kurang Praktis \\
\hline $\bar{X} \leq 36,5$ & Tidak Praktis \\
\hline
\end{tabular}

Pengujian efektivitas produk yang dikembangkan dilakukan dengan melihat nilai tes akhir mahasiswa untuk mengukur kemampuan berpikir kreatif mahasiswa. Indikator keefektifan produk ditentukan dengan kriteria minimal terdapat $80 \%$ dari jumlah mahasiswa yang diberikan tes mendapat skor kemampuan berpikir kreatif sebesar 75. Sedangkan pengujian efek potensial desain pembelajaran dalam meningkatkan kemampuan berpikir kreatif mahasiswa diuji dengan melihat peningkatan mean kemampuan berpikir kreatif menggunakan desain One Group Pretest and Postes.

\section{Hasil Penelitian}

\section{Tahap Penelitian Pendahuluan}

Penelitian pendahuluan dimaksudkan untuk need assesment terhadap pembelajaran yang dilakukan dosen program studi. Berdasarkan penelitian pendahuluan diperoleh gambaran tentang pelaksanaan pembelajaran yang dilakukan dosen program studi Pendidikan Matematika Universitas Hamzanwadi selama ini. Hasil pengamatan dan wawancara dengan beberapa dosen program studi pendidikan matematika, pembelajaran yang dilakukan belum menunjukkan pembelajaran yang melibatkan mahasiswa dalam menstruktuisasi aktivitas pembelajarannya dalam memecahkan masalah. Sementara itu, berdasarkan angket yang diberikan kepada 25 
mahasiswa Program studi Pendidikan Matematika menunjukkan bahwa 74,63\% mahasiswa merasakan dalam pembelajaran dosen belum sepenuhnya melakukan pembelajaran yang berorientasi pada mahasiswa yakni pembelajaran yang melibatkan mahasiswa secara aktif dalam mengembangkan kemampuan berpikir kreatif ketika mahasiswa dihadapkan pada persoalan pemecahan masalah matematika. Berdasarkan analisis kebutuhan tersebut, perlu dikembangkan perangkat pembelajaran matematika yang melibatkan mahasiswa secara aktif sehingga pembelajaran menjadi lebih bermakna, mahasiswa mampu menggunakan gagasan dan ide baru dalam memecahkan masalah serta mahasiswa mampu mengembangkan kemampuan berpikir kreatifnya

\section{Tahap Desain Produk}

Produk berupa desain pembelajan berbasis pengajuan dan pemecahan masalah disusun berdasarkan analisis kebutuhan terkait dengan proses pembelajaran yang dilakukan dosen seperti pada penelitian pendahuluan yang telah dilakukan. Kegiatan yang dilakukan pada tahap ini meliputi (1) penetapan tujuan pembelajaran yang akan dilakukan, (2) menyusun draf desain pembelajaran menggunakan model yang dilipih, (3) menyusun materi pembelajarann yang sesuai, dan (4) merancang evaluasi peneilaian yang akan digunakan. Pada tahap desain produk ini diperoleh produk berupa draf desain pembelajaran pada konsep volume benda putar dengan model pengajuan dan pemecahan masalah.

\section{Tahap pengembangan dan Evaluasi}

\section{Validitas Produk}

Draf produk yang telah dikembangkan selanjutnya divalidasi oleh 1(satu) orang ahli ahli materi pendidikan dan pembelajaran dan satu praktisi pelaksana pembelajaran. Analisis data hasil validasi oleh ahli dengan mengacu kriteria kevalidan pada tabel 2. Dari hasil validasi yang telah dilakukan disimpulkan bahwa produk desain pembelajaran konsep volume benda putar yang dirancang memuhi kriteria kevalidan yang ditetapkan seperti pada tabel $1 \mathrm{di}$ atas dengan kategori valid dan layak serta diputuskan tidak revisi, seperti ditunjukkan pada tabel 3 berikut 
Tabel 3. Ringkasan Penilaian Produk Desain Pembelajaran dengan Model Pengajuan dan Pemecahan Masalah

\begin{tabular}{lccc}
\hline \multicolumn{1}{c}{ Validator } & Tingkat Validitas & Kategori & \multicolumn{2}{c}{ Keputusan Uji } \\
\hline Ahli Materi & 252 & Valid dan layak & Tidak revisi \\
\hline Praktisi Pelaksana Pembelajaran & 257 & Valid dan Layak & Tidak revisi \\
\hline
\end{tabular}

\section{Kepraktisan Produk}

Kepraktisan produk yang dikembangkan didasarkan atas skor penilaian angket kepraktisan oleh pendapat ahli dan praktisi pembelajaran dengan menggunakan kriteria kepraktisan seperti pada tabel 3. Berdasarkan data angket yang dikumpulkan bahwa produk yang dikembangkan dalam kategori praktis dan dapat dilihat seperti pada tabel 4 di bawah.

Tabel 4. Hasil Penilaian Kepraktisan Produk Desain Pembelajaran dengan Model Pengajuan dan Pemecahan Masalah

\begin{tabular}{ccl}
\hline Ahli & Tingkat Kepraktisan & Kategori \\
\hline Ahli Materi & 70 & Praktis \\
\hline Praktisi Pelaksana Pembelajaran & 67 & Praktis \\
\hline
\end{tabular}

\section{Keefektifan Produk}

Efektivitas penggunaan produk yang dikembangkan dilihat dari nilai tes akhir mahasiswa setelah mengikuti pembelajaran konsep volume benda putar dengan desain pembelajaran berbasis pengajuan dan pemecahan masalah. Indikator keefektifan produk ditentukan dengan kriteria minimal $80 \%$ dari jumlah mahasiswa mendapat skor kemampuan berpikir kreatif sebesar 75. Hasil analisis data hasil belajar mahasiswa ditunjukkan seperti pada tabel 5 berikut.

Tabel 5. Hasil Tes Hasil Belajar Mahasiswa Setelah Pembelajaran

\begin{tabular}{lccc}
\hline & \multicolumn{3}{c}{ Skor Kemampuan berpikir kreatif } \\
\hline & $(\geq \mathbf{7 5})$ & $(<\mathbf{7 5})$ & Total \\
\hline Jumlah mahasiswa & 29 & 5 & 34 \\
\hline Prosentase & 85,29 & 14,71 & 100 \\
\hline
\end{tabular}

Mengacu pada tabel 5 yang disajikan di atas terlihat bahwa dari 34 mahasiswa sebagai subyek penelitian terdapat 29 mahasiswa atau 85,29\% yang mendapatkan skor kemampuan berpikir kreatif $\geq 75$. Dengan demikian produk yang dikembangkan efektif untuk digunakan.

Pengujian apakah desain pembelajaran yang dikembangkan potensial dalam meningkatkan kemampuan berpikir kreatif mahasiswa dilakukan melalui ujicoba produk dengan menerapkan desain pembelajaran yang dirancang selama 4 kali tatap muka. Pada akhir pembelajaran, mahasiswa diberikan tes hasil belajar tentang kemampuan berpikir kreatif pada konsep volume benda putar. Skor pretes dan postest serta nilai N-Gain digunakan untuk menentukan apakah desain pembelajaran yang dirancang potensial dalam kaitannya dengan 
peningkatan kemampuan berpikir kreatif mahasiswa. Berdasarkan perhitungan analisis didapatkan rerata pretest kemampuan berpikir kreatif mahasiswa sebesar 34,90 dan skor rata rata posttest sebesar 82,35 yang ditunjukkan dalam tabel 6 berikut.

Tabel 6. Nilai N-Gain Skor Pretest Posttest Hasil Belajar Mahasiswa Pada Konsep Volume Benda Putar

\begin{tabular}{llllll}
\hline $\mathbf{N}$ & \multicolumn{4}{c}{ Rata-rata (Mean) } & Kategori \\
\hline & Pretest & Posttset & Gain & N-Gain & \\
\hline 34 & 34,90 & 82,35 & 47,45 & 0,73 & Tinggi \\
\hline
\end{tabular}

Berdasarkan tabel 6, selisih rata rata skor pretest dan postest sebesar 47,45. Dengan asumsi skor maksimal perolehan nilai posttest sebesar 100 maka diperoleh N-Gain yaitu sebesar 0,73 termasuk kriteria tinggi. Hal ini menunjukan bahwa penggunaaan desain pembelajaran dengan model pengajuan dan pemecahan masalah berkontribusi dan berpotensi dalam meningkatkan dan mengembangkan kemampuan berpikir kreatif mahasiswa.

\section{Pembahasan}

Proses kegiatan belajar dan mengajar menggunakan desain permbelajaran berbasis pengajuan dan pemecahan masalah, mahasiswa dapat menggunakan ide, wawasan dan gagasan baru serta dapat mengkombinasikannya untuk memahami konsep dan mengatasi masalah yang akan dipecahkannya. Produk yang dikembangkan, dirancang agar mahasiswa tertantang dan mampu memilih ide kreatif yang dimiliki dalam menyelesaikan permasalahan. Selain itu pembelajaran dengan menggunakan model pengajuan dan pemecahan masalah, mahasiswa dituntut untuk terlibat secara aktif sehingga dapat merangsang perkembangan berpikir kreatif mahasiswa. Dengan demikian penerapan pembelajaran dengan menggunakan desain pembelajaran ini dapat membantu mahasiswa dalam mengembangkan kreativitasnya melalui ide ide dan gagasan gagasan baru selama mengikuti proses pembelajaran. Berdasarkan hal tersebut di atas, produk yang dikembangkan yaitu desain pembelajaran melalui model pengajuan dan pemecahan Masalah berpotensi dalam membantu meningkatkan dan mengembangkan proses berpikir kreatif mahasiswa.

\section{Simpulan}

Produk yang telah disusun dan dirancang yaitu berupa desain pembelajaran pada konsep volume benda putar telah memenuhi kriteria baik dari segi kevalidan, kepraktisan, keefektifan 
serta segi potensial dalam meningkatkan kemampuan berpikir kreatif mahasiswa. Berdasarkan penilaian validator, desain pembelajaran yang dikembangkan tergolong valid dan layak digunakan baik validator dari ahli materi maupun praktisi pelaksana pembelajaran setelah skor penilaian dari lembar validasi oleh validator termasuk kategori valid berdasarkan kriteria kevalidan yang ditetapkan. Produk yang dikembangkan juga tergolong praktis praktis digunakan berdasarkan skor penilaian angket kepraktisan oleh pendapat ahli dan praktisi pembelajaran dengan menggunakan kriteria kepraktisan yang ditetapkan. Produk yang dirancang dan dikembangkan juga tergolong efektif, tergambar dari prosentase mahasiswa yang mendapat skor tes kemampuan berpikir kreatif $\geq 75$ sebesar 85,29\% lebih tinggi dari indikator keefektifan produk yang ditetapkan yaitu sebesar 80\%. Disamping itu, desain pembelajaran yang dirancang juga memberikan dampak dan berpotensi dalam meningkatkan kemampuan berpikir kreatif mahasiswa. Hal ini nampak dari nilai N-Gain termasuk dalam kategori tinggi yaitu sebesar 0,73 .

\section{Referensi}

Amalina, I., Amirudin, K., \& Siswono. T. Y. (2018). Kemampuan berpikir kreatif siswa dalam pengajuan masalah semi terstruktur. Jurnal Riset Pendidikan dan Inovasi Pembelajaran Matematika, 2(1), 40-49. https://doi.org/10.26740/jrpipm.v2n1.p040-049.

Bengi, B. (2015). Creative and critical thinking skills in problem-based learning environments. Journal of Gifted Education and Creativity, 2(2), 71-80. https://doi.org/10.18200/JGEDC.2015214253.

Borg, W. R. \& Gall. (2007). Education research: An introduction. New York \& London: Logman.

Cindy, E., Silver, H., \& Chinn, C. A. (2013). The international handbook of collaborative learning. New York: Routledge.

Coughlan, A. (2007). Learning to learn: Creative thinking and critical thinking. Dublin: DCU Student Learning Resources.

Dick, W., \& Carey, L. (2001). The systematic design of instruction. New York: Addision Wesley

Gregoire, J. (2016). Understanding creativity in mathematics for improving mathematical education. Journal of Cognitive Education and Psychology, 15, 24-36. https://doi.org/10.1891/1945-8959.15.1.24.

Indriyani, A., Budiyono, \& Setiawan, R. (2017). Eksperimentasi pembelajaran matematika melalui model pembelajaran pengajuan dan pemecahan masalah (jucama) dan problembased learning pada materi segi empat ditinjau dari kreativitas belajar siswa kelas vii semester genap SMP N 1 Karanganom Tahun Pelajaran 2014/2015. Jurnal Pendidikan Matematika dan Matematika, 1(5), 1-9

Khaulah, S. (2018). Penerapan model pembelajaran jucama dengan menggunakan blok aljabar untuk meningkatkan kemampuan berfikir kreatif siswa pada materi persamaan kuadrat. Jurnal Pendidikan Almuslim, 6(2), 75-83 
Lambertus, Arapu, L., \& Patih, T. (2013). Penerapan pendekatan open-ended untuk meningkatkan kemampuan berpikir kreatif matematik siswa SMP. Jurnal Pendidikan Matematika. 4(1), 73 - 82. https://doi.org/10.22342/jpm.4.2.317.

Mahmudi, A. (2008). Pemecahan masalah dan berpikir kreatif. Konferensi Nasional Matematika XIV, Universitas Sriwijaya, Palembang.

Mahmudi, A. (2009). Mengembangkan kemampuan berpikir kreatif siswa melalui pembelajaran topik pecahan. Diakses dari http://staff.uny.ac.id/sites/default/files/penelitian/Ali\%20Mahmudi,\%20S.Pd,\%20M.P d,\%20Dr./Makalah\%2005\%20Semnas\%20ALJABAR\%20UNY\%202009\%20_Menge mbangkan\%20KB KM\%20via\%20Pecahan_.pdf pada 10 Februari 2020.

Nadjafikhah, M., \& Yaftian, N. (2013). The frontage of creativity and mathematical creativity. Procedia - Social and Behavioral Sciences, 90, 344-350. https://doi.org/10.1016/j.sbspro.2013.07.101.

NCTM. (2000). Principles and standards for school mathematics. Virginia: NCTM.

Novianti, E. D. \& Khoirotunnisa, U. A. (2016). Pengembangan perangkat pembelajaran berbasis pengajuan dan pemecahan masalah pada matakuliah program linear prodi pendidikan matematika IKIP PGRI Bojonegoro. Jurnal Ilmiah Pendidikan Matematika, 5(1), 11-16. https://doi.org/10.25273/jipm.v5i1.850.

OECD. (2016). PISA 2015 in focus. Paris: OECD.

Ridwan, H. N. (2018). Pengaruh penerapan metode pengajuan masalah dan metode pemecahan masalah terhadap kemampuan berfikir kreatif siswa. Indonesian Journal of Economics Education, 1(1), 103-112. https://doi.org/10.32616/pgr.v1.1.9.103-114.

Ridong, H., Xiaohui, S., \& Shieh, C. (2017). A study on the application of creative problemsolving teaching to statistics teaching. Eurasia, 13(7), 3139-3149. https://doi.org/10.12973/eurasia.2017.00708a.

Romadiastri, Y. (2013). Penerapan pembelajaran kontekstual pada Kalkulus 2 bahasan volume benda putar. Jurnal Phenomenon, 1(1), 131-143. https://doi.org/10.21580/phen.2013.3.1.179.

Siswono, T. Y. E. (2005). Upaya meningkatkan kemampuan berpikir kreatif siswa melalui pengajuan masalah. Jurnal Pendidikan Matematika dan Sains, 10(1), 1-9.

Siswono, T. Y. E. (2018). Pembelajaran matematika berbasis pengajuan dan pemecahan masalah fokus pada berpikir kritis dan berpikir kreatif. Bandung: PT Remaja Rosdakarya.

Yanti, M. N., Sudia, M., Arapu, L. (2019). Pengaruh model pembelajaran mind mapping terhadap kemampuan berpikir kreatif matematis peserta didik kelas VIII SMP Negeri 8 Konawe Selatan. Jurnal Penelitian Pendidikan Matematika, 7(3), 71-84. 